\title{
OPTIMIZATION OF THE ANAEROBIC DIGESTION PROCESS BY USING MULTI-CRITERIA ANALYSIS
}

\author{
UDC 628.477.4
}

\section{Milica Ivanović ${ }^{1}$, Gordana Stefanović ${ }^{1}$, Predrag Rajković ${ }^{1}$, Biljana Milutinović ${ }^{2}$}

${ }^{1}$ Faculty of Mechanical Engineering, University of Niš, Niš, Serbia

${ }^{2}$ College of Applied Technical Sciences, Niš, Serbia

\begin{abstract}
Anaerobic co-digestion (AcD) of various fractions of organic wastes $(O W)$ is a good method to solve the problem of $O W$ management and energy recovery. The process is influenced by many factors, such as physical and chemical characteristics of the waste. This study is engaged with optimization of AcD process investigation; a mathematical model was developed, on the basis of characteristics of $O W$ with the aim to achieve a maximum biogas production. Different fractions of $O W$ available at the territory of the city of Niš, organic fractions of municipal waste (OFMSW), cow manure $(C M)$, pig manure (PM), wheat straw (WS), maize silage (MS), hen manure (HM) and a theory-calculated amount of sludge from wastewater treatment plant (WWS) were observed. By applying a multi-criteria optimization and observing a carbon, nitrogen, lipid and lignin content in $\mathrm{OW}$, a mathematical model was developed. The criteria for the model were to achieve a maximum carbon and lipid content and minimize nitrogen and lignin content. Two different mixtures of $O W$ were also examined. The first mixture included OFMSW, CM, PM, MS, HM, WS, whereas the second one included the fractions from the first mixture and sludge from the wastewater treatment plant. The results show that in the first optimal mixture there is 10\% of HM, 10\% PM and $10 \% \mathrm{MS}, 24 \%$ OFMSW, $34 \% \mathrm{CM}$, and $12 \% \mathrm{WS}$. The share of carbon is $44.1 \%$, nitrogen $2.4 \%$, lipid $5.8 \%$, and lignin $3.9 \%$, while the $\mathrm{C} / \mathrm{N}$ ratio is 17.7 . The content of the second optimal mixture involves $10 \%$ of HM, $10 \%$ of PM, $10 \%$ of MS, and $10 \%$ of WWS, 23\% of OFMSW, 26\% of CM, and 11\% of WS. Carbon content is 43.2\%, nitrogen $2.7 \%$, lipid $6.1 \%$ and lignin $4.1 \%$, while the C/N ratio is 15.6. From the aspect of biogas production, the results showed that the first optimal mixture had $17.6 \%$ higher production than the second optimal mixture.
\end{abstract}

Key words: anaerobic co-digestion, organic waste, lipids, lignin, biogas production, $\mathrm{C} / \mathrm{N}$ ratio.

Received March 5, 2019 / Accepted April 22, 2019

Corresponding author: Milica Ivanović

Faculty of Mechanical Engineering, University of Niš, Aleksandra Medvedeva 14, 18000 Niš, Serbia

E-mail: milicaivanovic1405@gmail.com 


\section{INTRODUCTION}

Anaerobic digestion (AD) is one of the most commonly used OW treatments, in which the final products are biogas and digestate. In comparison to $\mathrm{AD}$, the anaerobic co-digestion (AcD) process has several advantages: improving nutrients balance and $\mathrm{C} / \mathrm{N}$ ratio, reducing inhibitory effects and improving the kinetics of methane production [1]. The AcD process is influenced by many factors, such as temperature, $\mathrm{C} / \mathrm{N}$ ratio, $\mathrm{pH}$ value, but also the characteristics of OW that is treated. For example, research has shown that biogas production is higher if the particle size of OW is smaller [2]. Proteins, carbohydrates and lipids are the basic components of $\mathrm{OW}$ and each of them has an important effect on the AcD process. Studies have shown that OW rich in proteins is the most suitable for AcD treatment, while carbohydrates that are highly degradable can cause problems if present in large amounts along with amino acids [3]. Lipids and carbohydrates, with particular reference to lignins, which were observed in this paper, have an inhibiting effect on the AcD process.

The term lipid refers to fat, oil and grease (FOG), whose elemental composition is made of up to $76 \%$ of carbon, $12 \%$ of hydrogen and $12 \%$ of oxygen [4]. Lipids are present in various fractions of $\mathrm{OW}$, such as food residues, waste sludge, and $\mathrm{OW}$ from various industries. The issue with lipids is that they can cause operational, heat and mass transfer problems because they are absorbed in the surface of microbiological mass and on the equipment in the AcD process [5]. Long-chain fatty acids (LCFA), which are present in the composition of lipids, also have a negative effect on the AcD process, because they are toxic [6]. However, although they have a negative effect, lipids have become increasingly interesting for research, due to the fact that they result in high biogas production with high methane content [7]. During the AD process, lipids are first hydrolysed to glycerol and free LCFA. Then, by acidogenesis, glycerol is converted to volatile fatty acids (VFA), while LCFA is converted to hydrogen and carbon dioxide, under the influence of $\beta$ - oxidizer, and converted into VFA. By acetogenesis, VFA is then converted into acetic acid, and finally by the methanogenesis process into $\mathrm{CH}_{4}$ and $\mathrm{CO}_{2}$ [8]. It is shown that the production of methane increases from 13 to $197 \%$ if the treated OW contains $30-60 \%$ of lipids in the total volatile solids (VS) [9]. Also, there have been many studies regarding the maximum concentration of lipids in the substrate, in which OFMSW and waste sludge were treated. It has been experimentally shown that the optimal concentration of lipids is $60 \%$ of the total VS. At this concentration, methane yield is the highest, while the $\mathrm{pH}$ value is optimal. If the concentration is higher than $60 \%$, the inhibition of process occurs and the $\mathrm{pH}$ value is reduced [10]. In addition to the previous research, the process of co-digestion of grease trap sludge with sewage sludge (SS) was also studied, under mesophilic conditions, when the lipid concentration is $5-55 \%$. The results showed that if the concentration of grease trap sludge was below $46 \%$, the methane production increased, but when the concentration of grease trap sludge was raised to $55 \%$, the methane production began to decrease [11].

Lignin, along with hemicellulose and cellulose, represents lignocellulose, which belongs to the group of carbohydrates. OW, such as grass, hay, silage, etc., which is rich in lignocellulose, is widely used as a cosubstrate in the $\mathrm{AcD}$ process due to its high $\mathrm{C} / \mathrm{N}$ ratio. However, OW rich in lignin and cellulose is unsuitable for biodegradation under anaerobic conditions. As a reason behind this, it can be stated that during the AcD process these carbohydrates limit the decomposition of matter, which reduces the production of biogas, while together with the rest of the undecomposed substrate the process remains unchanged. Their non-degradability or low degradability during the AcD process is due to the fact that 
extracellular enzymes require oxygen for depolymerization. Hydrolysis of cellulose in lignocellulosic materials is reduced by lignins and lignocelluloses, as these components act as a protective layer, which makes cellulose resistant to enzymatic digestion. Various methods, such as thermal, chemical, thermochemical and biological, are used to improve the degradation of lignin during the $\mathrm{AD}$ process. In this way, the destruction of the lignocellulose matrix is achieved, which leads to easier hydrolysis of carbohydrates. By way of the further decomposition process, carbohydrates are converted into sugar monomers, and at the end of the decomposition process, the final products are $\mathrm{CH}_{4}$ and $\mathrm{CO}_{2}$. It is shown that if the $\mathrm{OW}$, that is rich in lignins, is treated first at higher temperatures and then treated with the classic $\mathrm{AD}$ process, higher methane production can be obtained than in the case where the $\mathrm{OW}$ is immediately treated with the AD process[12][13][14].

There are different methods for the optimization of $\mathrm{AD}$ and $\mathrm{AcD}$ processes, and they can be divided into five categories: classical kinetic models, ADM1, statistical models, computational fluid dynamics (CFD), and other applied algorithms. What these methods have in common is that they follow the kinetics of the AD or AcD process, where HRT, ORL, COD, substrate characteristics are used as input parameters [15]. The most widely used method is ADM1, developed by the IWA AD modelling Task Group. This method is the most complex because it follows every phase of the AD process [16]. In addition to previous studies, which have observed only those parameters only that the influence the $\mathrm{AD}$ process, a new piece of research that has been conducted, shows that it is possible to reduce operating costs and get a maximal biogas production by applying a fuzzy multiobjective optimization [17].

Unlike mathematical models that tend to describe the process in real conditions, classical methods such as multi-criteria optimization (MCO) can also be used to optimize the AD process. The most commonly used methods of MCO are the lexicographic method, $\varepsilon$-Constraint method, global criteria method, and weight coefficient method. For some methods, it is necessary to perform parameter ranking and work out a solution on the basis of this, or it is necessary to introduce constraints, where the optimal point of the solution must satisfy these constraints. The global criterion method does not require ranking of the criteria since it treats them as equals. These methods can be applied in cases where it is necessary to select which fractions of OW should be mixed and what the portions of those fractions should be, where parameters such as $\mathrm{C} / \mathrm{N}$ ratio, lipid, protein, and lignin content, etc., or parameters that depend on the substrate characteristics, should be used as conditions. Also, these methods can be the basis for the development of other methods that tend to describe $\mathrm{AD}$ and involve other more important factors that affect the AD process.

In this paper, a mathematical model was developed in order to obtain an optimum mixture of different fractions of $\mathrm{OW}$ with the aim to achieve the maximum production of biogas, by using the method of the global criterion. Seven different fractions of OW were observed: HM, OFMSW, CM, PM, MS, WS and WWS. The components that were observed in this paper are carbon, nitrogen, lipids, and lignins because each of them has an impact on biogas production and depends on the composition of OW. The conditions introduced during the formation of the mathematical model are the $\mathrm{C} / \mathrm{N}$ ratio, which is in the range of 15-25, but also different portions of fractions. Two different cases and two different mixtures were observed, with the aim to get an optimal mixture of OW. This model was developed for the case of the city of Niš, with the aim of neutralizing OW in the city. 


\section{MATERIALS AND METHODS}

\subsection{Multi-criteria optimization}

MCO is part of a mathematical field that deals with the simultaneous optimization of more targeted functions. The main goal of MCO is to find the best solution for all considered criteria at the same time, while factors or outcomes that influence the process itself are considered as criteria. Although MCO has a wide application, in manufacturing, engineering problems, design, it is very difficult to find a complete solution - the best or preferred solution, which will meet all the criteria. In order to find an optimal solution, the concept of Pareto optimum is introduced, with the aim of finding the so-called dominant solution. The condition that there is a dominant solution is that there is no other dominant solution that would be better by any criterion. This means that the improvement of at least one criteria relative to the dominant solution would be accompanied by a deterioration of some of the other criteria. It is important that, when developing MCO methods, the solutions that are obtained be dominant, with the decision maker choosing the best solution based on the value of the criteria.

\subsection{Mathematical model for the optimization of the AD process}

For a model forming, MCO was applied, with the aim to develop a mathematical model for different fractions of $\mathrm{OW}$ in order to achieve the maximum biogas production. Starting from the elementary composition, carbon and nitrogen content, $\mathrm{C} / \mathrm{N}$ ratio, as well as the share of lipids and lignins in waste, a mathematical model with input data was formed. During the development of the model, it was realized that all the criteria should be satisfied since the functions (processes) are happening simultaneously.

For the development of the model, based on the input data, the following functions were developed:

$$
\begin{aligned}
& C(x)=\sum_{i=1}^{n} C_{i} x_{i} \\
& L_{1}(x)=\sum_{i=1}^{n} L_{i} x_{i} \\
& L_{2}(x)=\sum_{i=1}^{n} L_{i} x_{i} \\
& N(x)=\sum_{i=1}^{n} N_{i} x_{i}
\end{aligned}
$$

Where $\mathrm{C}$ - represents the share of carbon in $\mathrm{OW}$ in (\%), $\mathrm{N}$ - represents the share of nitrogen in OW in (\%), $L_{1}$ - represents the share of lipids in OW in (\%) and $L_{2}$ - represents the share of lignin in OW. Parameter $x,\left(x_{1}, x_{2}, x_{3}, x_{4}, x_{5}, x_{6}, x_{7}\right)$, in the first case, $x,\left(x_{1}, x_{2}, x_{3}, x_{4}, \mathrm{x}_{5}, x_{6}, x_{7}\right)$ in the second case, represents a mixture of OW, where $n$ denotes the number of fractions in the mixture in percentage (\%).

Once the model has been developed, it is necessary to introduce the conditions. The first condition in the mathematical model for both cases is:

$$
\begin{gathered}
x_{1}+x_{2}+x_{3}+x_{4}+x_{5}+x_{6}=1 \\
x_{1}+x_{2}+x_{3}+x_{4}+x_{5}+x_{6}+x_{7}=1
\end{gathered}
$$

because the sum of the percentage of fractions in the mixture is $100 \%$, where $x_{i} \geq 0$, for each $i$. 
The next condition is the $\mathrm{C} / \mathrm{N}$ ratio. It is recommended that the $\mathrm{C} / \mathrm{N}$ ratio is in the range between 20 and 30 for the $\mathrm{AD}$ process. Although this ratio is recommended, laboratory testing has shown that the $\mathrm{C} / \mathrm{N}$ ratio can be lower than 20 , and the maximum production of biogas is achieved in that case [18]. The next condition is $15 \leq C(x) / N(x) \leq 25$. On this basis, the following two boundary conditions in the mathematical model can be formed:

$$
C(x)-15 N(x) \geq 0,25 N(x)-C(x) \geq 0
$$

In addition to the previous conditions, the portions of some fractions were supposed to be different, in order to include all OW fractions in the composition of the optimal mixture. Therefore, the boundary conditions for both cases are:

For the first case:

$$
\begin{gathered}
0.1 \leq x_{1} \leq 1 \\
0.01 \leq x_{2} \leq 0.5 \\
0.01 \leq x_{3} \leq 0.5 \\
0.1 \leq x_{4} \leq 1 \\
0.1 \leq x_{5} \leq 0.5 \\
0.1 \leq x_{6} \leq 0.5
\end{gathered}
$$

For the second case:

$$
\begin{gathered}
0.1 \leq x_{1} \leq 1 \\
0.01 \leq x_{2} \leq 0.5 \\
0.01 \leq x_{3} \leq 0.5 \\
0.1 \leq x_{4} \leq 1 \\
0.1 \leq x_{5} \leq 0.5 \\
0.1 \leq x_{6} \leq 0.5 \\
0.1 \leq x_{7} \leq 1
\end{gathered}
$$

The reason for the introduction of different portions of OW fractions is that the individual fractions are present in larger or smaller quantities. Fractions with a larger range such as $x_{1}, x_{4}$ and $x_{7}$ have an inadequate parameter $(\mathrm{C} / \mathrm{N})$, while $x_{2}, x_{3}, x_{6}, x_{5}$ have a better $\mathrm{C} / \mathrm{N}$ ratio, and therefore, their range is lower. By mixing fractions in different portions, an optimal $\mathrm{C} / \mathrm{N}$ ratio would be achieved, with the aim to use the fractions with inadequate parameters in larger portions in the mixture. After defining all boundary conditions, an allowable range in which it is necessary to find optimal solutions is defined. The mathematical formulation of the criteria based on equations (1) is:

$$
\begin{aligned}
& \max _{x \in D} C(x)=\sum_{i=1}^{n} C_{i} x_{i} \\
& \max _{x \in D} L_{1}(x)=\sum_{i=1}^{n} L_{i} x_{i} \\
& \min _{x \in D} L_{2}(x)=\sum_{i=1}^{n} L_{i} x_{i} \\
& \min _{x \in D} N(x)=\sum_{i=1}^{n} N_{i} x_{i}
\end{aligned}
$$


The global criterion method was used in order to solve the MCO problem. The global criterion method is simple and does not require any criteria preference. After determining the ideal values of the criteria, an auxiliary single-criterion model with limitations is formed, as in the model and function of the criteria:

$$
\min G(x)=\left(\frac{C^{*}-C(x)}{C^{*}}\right)^{2}+\left(\frac{L_{1}^{*}-L_{1}(x)}{L_{1}^{*}}\right)^{2}+\left(\frac{L_{2}^{*}-L_{2}(x)}{L_{2}^{*}}\right)^{2}+\left(\frac{N^{*}-N(x)}{N^{*}}\right)^{2}
$$

The solution equals the minimum value of a single criterion model, and it represents a selected variant of the collection of normalized distances between the values obtained and the ideal values of the criteria.

\section{EXPERIMENTAL RESEARCH}

The previously presented model for the optimization of different organic fractions for maximum biogas production is developed in the city of Niš. Two different cases were observed. In the first case, there was no wastewater treatment plant, while in the second one there was a plant for wastewater treatment.

\subsection{Study area}

The City of Niš has about 260,000 inhabitants, with the land area of $596,71 \mathrm{~km}^{2}$, comprising five urban municipalities with 70 suburban and rural settlements [19]. Currently, about 65,348 tonnes of waste are generated annually, out of which 17,866 t/year of OW, which contains food waste and garden waste [20]. The amount of wastewater removed by the sewerage system is $40 \%$ of the total number of population equivalent (PE), on the basis of which the number of PE for the city of Niš is 104,095 [21]. In order to determine the amount of sludge that occurs after the treatment of wastewater, the biological load was taken to be $60 \mathrm{~g}$ TS/PE per day. Based on this, the amount of sludge is estimated to be $99,4 \mathrm{~m}^{3} /$ day, and it consists of primary and secondary sludge. In the city territory, there are currently 8,367 farms, while the arable land occupies 13,062.54 ha. The area under wheat is 3,889 ha, and under maize 3,785 ha. The total number of domestic animals is 151,818 . There are 2,870 heads of cattle, 15,292 pigs while the number of poultry is 128,065 [22] [23].

Table 1 Quantities of organic matter in the territory of the city of Niš [24]

\begin{tabular}{cccccccc}
\hline Fractions & $\begin{array}{c}\text { Number of } \\
\text { inhabitants, } \\
\text { animals, ha }\end{array}$ & $\begin{array}{c}\text { Density } \\
{\left[\mathrm{kg} / \mathrm{m}^{3}\right]}\end{array}$ & \multicolumn{2}{c}{$\begin{array}{c}\text { Quantity } \\
\text { [capita/th/ha]/year }\end{array}$} & \multicolumn{2}{c}{$\begin{array}{c}\text { Total quantity } \\
\text { [capita/th/ha]/year }\end{array}$} \\
\cline { 6 - 8 } & & & & $\mathrm{m}^{3}$ & $\mathrm{t}$ & $\mathrm{m}^{3}$ & $\mathrm{~T}$ \\
\hline $\begin{array}{c}\text { Communal waste } \\
\text { WWS }\end{array}$ & 104,095 & 1030 & 0.3485 & 0.3585 & $36,277.1$ & $37,365.4$ \\
OFMSW & 260,237 & 1000 & 0.0686 & 0.0686 & 17,866 & 17,866 \\
\hline Animal excrements & & & & & & \\
CM & 2,870 & 993 & 20 & 19.86 & 57,400 & $56,998.2$ \\
PM & 15,292 & 993 & 1.46 & 1.44 & $22,326.3$ & $22,168.8$ \\
HM & 128,065 & 1009 & 0.0644 & 0.0649 & $8,249.9$ & 8324.2 \\
\hline Biomass & & & & & & \\
WS & 3,889 & 100 & 33.9 & 3.39 & $131,837.1$ & $13,183.7$ \\
MS & 3,785 & 100 & 40.6 & 4.06 & 153,671 & $15,367.1$ \\
\hline
\end{tabular}




\subsection{Making a mathematical model}

With the aim to achieve the maximum biogas production, while taking into account the available fractions on the territory of the city of Niš (such as HM, OFMSW, PM, CM, WS, MS and WWS), we managed to develop a mathematical model. Two different cases were observed (the existence or the absence of wastewater treatment facilities in the city). In the first case, without wastewater treatment plant, the main component would be OFMSW, and others, HM, MS, CM, PM, and WS should be cosubstrates. In the second case where there is a plant for wastewater treatment, and the main components in the mixture are FMSW and WWS, the cosubstrates could be CM, HM, MS, WS, and PM. The basic characteristics of these fractions are shown in Table 2. By applying MCO, the mathematical model was developed under the given conditions. The goal is to achieve maximum carbon and lipid content, and the minimum share of lignin and nitrogen, for both cases.

The data presented in Table 2 refer to the mass participation in percentage.

Table 2 The characteristics of the substrates

$[18,20,25,26,27,28,29,30,31,32,33,34,35,36]$

\begin{tabular}{|c|c|c|c|c|c|c|c|}
\hline \multirow{2}{*}{$\begin{array}{l}\text { Fraction } \\
\text { of waste }\end{array}$} & \multicolumn{6}{|c|}{$\%$, mass } & \multirow{2}{*}{$\begin{array}{c}\text { Biogas } \\
\text { production } \\
{\left[\mathrm{m}^{3} / \mathrm{kgVS}\right]}\end{array}$} \\
\hline & $\mathrm{C}$ & $\mathrm{N}$ & Lipid & Lignin & TS & VS(TS) & \\
\hline WWS & 36.5 & 4.9 & 6.9 & 4.2 & 3.7 & 65.7 & 0.18 \\
\hline OFMSW & 47.9 & 3.1 & 15.0 & 4.5 & 35.0 & 73.6 & 0.65 \\
\hline $\mathrm{CM}$ & 44.2 & 1.9 & 2.3 & 1.7 & 14.8 & 82.2 & 0.3 \\
\hline PM & 40.2 & 4.1 & 3.0 & 1.8 & 27.1 & 74.0 & $0.25-0.5$ \\
\hline $\mathrm{HM}$ & 36.2 & 3.6 & 8.7 & 2.0 & 24.9 & 78.1 & 0.4 \\
\hline MS & 48.1 & 2.6 & 1.9 & 11.6 & 27.9 & 94.9 & $0.35-0.55$ \\
\hline WS & 42.5 & 0.4 & 0.9 & 6.5 & 83.3 & 92.1 & 0.5 \\
\hline
\end{tabular}

Based on the previous table (Table 2) and the previous equations (1) and (5), a mathematical problem is set up for both cases:

The first case:

$$
\begin{gathered}
C(x)=36.2 x_{1}+47.9 x_{2}+44.2 x_{3}+40.2 x_{4}+48.1 x_{5}+42.5 x_{6} \\
N(x)=3.6 x_{1}+3.1 x_{2}+1.9 x_{3}+4.1 x_{4}+2.6 x_{5}+0.4 x_{6} \\
L_{1}(x)=8.7 x_{1}+15 x_{2}+2.3 x_{3}+3 x_{4}+1.9 x_{5}+0.9 x_{6} \\
L_{2}(x)=2 x_{1}+4.5 x_{2}+1.7 x_{3}+1.8 x_{4}+11.6 x_{5}+6.5 x_{6}
\end{gathered}
$$

The second case:

$$
\begin{gathered}
C(x)=36.2 x_{1}+47.9 x_{2}+44.2 x_{3}+40.2 x_{4}+48.1 x_{5}+42.5 x_{6}+36.5 x_{7} \\
N(x)=3.6 x_{1}+3.1 x_{2}+1.9 x_{3}+4.1 x_{4}+2.6 x_{5}+0.4 x_{6}+4.9 x_{7} \\
L_{1}(x)=8.7 x_{1}+15 x_{2}+2.3 x_{3}+3 x_{4}+1.9 x_{5}+0.9 x_{6}+6.9 x_{7} \\
L_{2}(x)=2 x_{1}+4.5 x_{2}+1.7 x_{3}+1.8 x_{4}+11.6 x_{5}+6.5 x_{6}+4.2 x_{7}
\end{gathered}
$$

By applying the equations (2, 3, and 4), an allowable range is obtained (D), which is being sought the solution: 
For the first case

$$
D:\left\{\begin{array}{c}
x_{1}+x_{2}+x_{3}+x_{4}+x_{5}+x_{6} \geq 1 \\
53.8 x_{1}+29.6 x_{2}+3.3 x_{3}+62.3 x_{4}+16.8 x_{5}-31.2 x_{6} \geq 0 \\
0.1 \leq x_{1} \leq 1 \\
0.01 \leq x_{2} \leq 0.5 \\
0.01 \leq x_{3} \leq 0.5 \\
0.1 \leq x_{4} \leq 1 \\
0.1 \leq x_{5} \leq 0.5 \\
0.1 \leq x_{6} \leq 0.5
\end{array}\right.
$$

For the second case:

$$
D:\left\{\begin{array}{c}
x_{1}+x_{2}+x_{3}+x_{4}+x_{5}+x_{6}+x_{7} \geq 1 \\
-17.8 x_{1}+1.4 x_{2}+15.7 x_{3}-21.3 x_{4}+9.1 x_{5}+35.7 x_{6}-37 x_{7} \geq 0 \\
53.8 x_{1}+29.6 x_{2}-3.35 x_{3}+62.3 x_{4}+16.8 x_{5}-31.2 x_{6}+85.9 x_{7} \geq 0 \\
0.1 \leq x_{1} \leq 1 \\
0.01 \leq x_{2} \leq 0.5 \\
0.01 \leq x_{3} \leq 0.5 \\
0.1 \leq x_{4} \leq 1 \\
0.1 \leq x_{5} \leq 0.5 \\
0.1 \leq x_{6} \leq 0.5 \\
0.1 \leq x_{7} \leq 1
\end{array}\right.
$$

\subsection{Biogas production}

According to the solutions of MCO for an optimal mixture, the biogas production for both cases can be calculated on the annual level, for the known quantities of OW on the territory of the City of Niš. In order to calculate the biogas production, the biogas production of $0.4 \mathrm{~m}^{3} / \mathrm{kgVS}$ was taken for the first case, and $0.37 \mathrm{~m}^{3} / \mathrm{kgVS}$ for the second case. If OW were treated under the mesophilic conditions of the AD, the previously mentioned production of biogas would be achieved. The assumptions for this model are: the mixture in the first case contains $35.5 \%$ of total solids (TS) (the share of volatile solids - VS is $82.5 \%$ of TS), while in the second case it contains $30.9 \%$ of TS (the share of VS is $80.1 \%$ of TS).

\section{RESULTS AND DISCUSSION}

The optimization of the AcD process is very complex since it is influenced by waste characteristics and other physical and chemical parameters. For a previously developed mathematical model, five different solutions have been obtained. The first four are solutions of a one criteria model - when it is necessary to achieve a maximum carbon and 
lipid content, minimum nitrogen and lignin content in mixtures. The last is an optimal solution and it includes all previous criteria solutions as well as the conditions that are set at the beginning of a mathematical model.

\subsection{Single-Criterion Problem}

The solutions of the single-criterion problem are obtained after applying the equations (1) and (5) and using the equation (7), the solutions that satisfy the conditions (2), (3) and (4) and they are located in an allowable range (D), equation (8). The mixture composition, for both cases and each criterion, is shown in Table $3 \mathrm{a}$ and Table $3 \mathrm{~b}$.

Table 3a The composition of the mixture after solving a single-criterion problem the first case

\begin{tabular}{|c|c|c|c|c|c|c|c|}
\hline $\begin{array}{l}\text { Fraction } \\
\text { criteria }\end{array}$ & & $\begin{array}{l}\mathrm{HM} \\
{[\%]}\end{array}$ & $\begin{array}{c}\text { OFMSW } \\
{[\%]}\end{array}$ & $\begin{array}{l}\mathrm{CM} \\
{[\%]}\end{array}$ & $\begin{array}{l}\mathrm{PM} \\
{[\%]}\end{array}$ & $\begin{array}{l}\mathrm{MS} \\
{[\%]}\end{array}$ & $\begin{array}{l}\text { WS } \\
{[\%]}\end{array}$ \\
\hline $\max (C)=C^{*}$ & $45.5 \%$ & 10 & 19 & 1 & 10 & 50 & 10 \\
\hline $\min (N)=N^{*}$ & $1.7 \%$ & 12.4 & 1 & 16.6 & 10 & 10 & 50 \\
\hline $\max \left(L_{1}\right)=L_{1}{ }^{*}$ & $9.7 \%$ & 18.5 & 50 & 1 & 10 & 10 & 10.5 \\
\hline $\min \left(L_{2}\right)=L_{2}{ }^{*}$ & $3.2 \%$ & 10 & 1 & 50 & 19 & 10 & 10 \\
\hline
\end{tabular}

Table 3b The composition of mixtures after solving a single-criterion problem the second case

\begin{tabular}{lcccccccc}
\hline $\begin{array}{l}\text { Fraction } \\
\text { criteria }\end{array}$ & $\begin{array}{c}\text { HM } \\
{[\%]}\end{array}$ & $\begin{array}{c}\text { OFMSW } \\
{[\%]}\end{array}$ & $\begin{array}{c}\text { CM } \\
{[\%]}\end{array}$ & $\begin{array}{c}\text { PM } \\
{[\%]}\end{array}$ & $\begin{array}{c}\text { MS } \\
{[\%]}\end{array}$ & $\begin{array}{c}\text { WS } \\
{[\%]}\end{array}$ & $\begin{array}{c}\text { WWS } \\
{[\%]}\end{array}$ \\
\hline $\max (C)=C^{*}$ & $44.3 \%$ & 10 & 9 & 1 & 10 & 50 & 10 & 10 \\
$\min (N)=N^{*}$ & $1.9 \%$ & 10 & 1 & 9 & 10 & 10 & 50 & 10 \\
$\max \left(L_{1}\right)=L_{1}{ }^{*}$ & $8.5 \%$ & 10 & 42.1 & 1 & 10 & 10 & 16.9 & 10 \\
$\min \left(L_{2}\right)=L_{2}{ }^{*}$ & $3.5 \%$ & 10 & 1 & 49 & 10 & 10 & 10 & 10 \\
\hline
\end{tabular}

From Table $3 \mathrm{a}$ and Table $3 \mathrm{~b}$ it can be seen that in the single-criterion problem when it is necessary to achieve maximum carbon content, the higher share of carbon has a mixture in the first case $(45.5 \%$ ), while in the second it is $44.3 \%$. The highest share is taken by MS, $50 \%$ and the lowest CM by $1 \%$ in both cases, while the share of OFMSW is $19 \%$ in the first case and $9 \%$ in the second case. The other fractions have a similar share in both cases. Obtained results (Table $3 \mathrm{a}$ and Table $3 \mathrm{~b}$ ) indicate that the $\mathrm{C} / \mathrm{N}$ ratio is higher in the second case.

In the second case, where it is necessary to achieve the minimum nitrogen content, the share of nitrogen is reduced to $1.7 \%$ in the first and $1.9 \%$ in the second case. From Table $3 \mathrm{a}$ and Table $3 \mathrm{~b}$, it can be seen that only WS takes a share of $50 \%$ in mixtures in both cases, and only two fractions - HM and OFMSW - have a higher share of $10 \%$ in the first case, whereas the other fractions have a lower share in a mixture.

In the third case, when it is necessary to achieve maximum lipid content in the mixture, the highest share of lipid has a mixture of $9.7 \%$ in the first case $9.7 \%$, and $8.7 \%$ in the second one. Also, the high share of lipid in the first case indicates that biogas production will be higher.

When the lignin content in the mixture is minimized, in the first case it is reduced to $3.2 \%$, and in the second to $3.5 \%$. In both mixtures, the highest share is taken by CM, about $50 \%$, and the lowest share has $1 \%$ of OFMSW. Other fractions, in both cases, have 
a similar share in the mixture, but only PM has a share of $19 \%$ in the first case. The second mixture has a higher share of lignin because there is one more fraction with high lignin content.

\subsection{Optimal solution}

In the fifth case, where it is necessary to get an optimal mixture of the input fractions, an MCO was applied. The following conditions were included: maximum carbon and lipid content and minimal nitrogen and lignin content, as well as the $\mathrm{C} / \mathrm{N}$ ratio, and an optimal mixture, were obtained, for both cases. Using the global criterion method, equation (6), on the previously obtained one criteria solutions $\left(C^{*}, N^{*}\right.$ and $L_{1}{ }^{*}$, and $\left.L_{2}{ }^{*}\right)$ from Table 3 a and Table $3 b$, the Pareto optimum was found. The solutions of the global criterion method are presented in Figure 1 and share of carbon, nitrogen, lipid and, lignin, also and $\mathrm{C} / \mathrm{N}$ ratio in Figure 2.

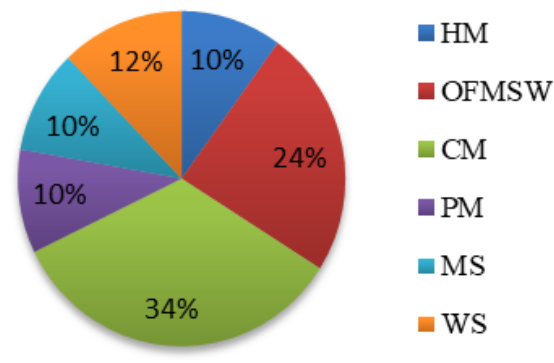

a)

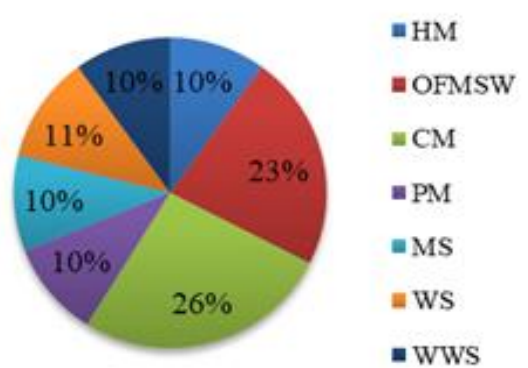

b)

Fig. 1 Optimal mixture composition a) the first case, b) the second case

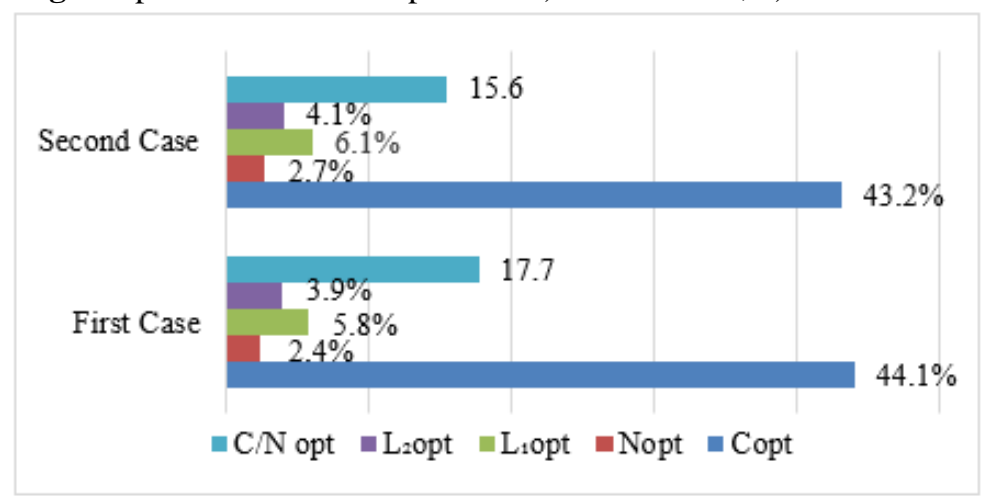

Fig. 2 Obtained values for Carbon, Nitrogen, Lipid, Lignin content, and C/N ratio

From Figure 2, it can be seen that in the first mixture, the share of carbon is $44.1 \%$, nitrogen $2.4 \%$, lipids $5.8 \%$ ad lignin $3.9 \%$. The $\mathrm{C} / \mathrm{N}$ ratio is 17.7 , which is in the given range. In the second mixture, the share of carbon is $43.2 \%$, nitrogen $2.7 \%$, lipids $6.1 \%$ and lignin $4.1 \%$, while the $\mathrm{C} / \mathrm{N}$ ratio is 15.6 . The second mixture has a higher share of nitrogen, lipid and lignin, while the carbon content is lower. Only the carbon content is 
higher in the first mixture. The $\mathrm{C} / \mathrm{N}$ ratios in both mixtures are in the given range, but the one in the first mixture is higher.

After applying the developed model of MCO for calculating the optimal mixture for the maximum biogas production on the territory of the city of Nišs, in the case where the entire amount OFMSW is treated $\left(17,866 \mathrm{~m}^{3} /\right.$ year $)$, the biogas production for the first mixture is $8,551,316.5 \mathrm{~m}^{3} /$ year. The quantities of the other fractions, which are presented in the optimal mixture composition in Figure 2 are 7,450.4 $\mathrm{m}^{3} /$ year HM, which is $90.3 \%$ of the annual production, $33.4 \%$ of PM, $4.8 \%$ of MS, $43.9 \%$ of CM and $6.8 \%$ of WS.

In the second mixture, the biogas production is 7,046,555.3 $\mathrm{m}^{3} /$ year. Also, in this mixture, OFMSW is the main fraction, while the other fractions are co-substrates. The quantities of the other fractions are $96.2 \%$ of HM of annual production, $35.5 \%$ of PM, $5.1 \% \mathrm{MS}, 36.4 \% \mathrm{CM}, 6.7 \% \mathrm{WS}$ and $21.8 \%$ of WWS.

It can be seen from previous calculations that biogas production is higher in the first case, about $17.6 \%$ higher than in the second case. That indicates if the WWS is presented in a higher share in the optimal mixture the biogas production and the $\mathrm{C} / \mathrm{N}$ ratio will be decreased. Another limiting factor in the second case is that WWS in his composition includes heavy metals, and obtained digestate cannot be used as a fertilizer, unlike in the first case where it is possible.

\section{CONCLUSION}

The production of biogas during the $\mathrm{AD}$ process depends on many factors. The characteristics of substrates have a particular influence on the production of biogas, as well as on the percentage of methane in biogas. In order to increase the production of biogas, different OW fractions are treated together. Seven different fractions of OW that are available at the territory of the city and two different cases have been observed in order to obtain the optimal mixture and achieve the maximum biogas production. The obtained results show that the first optimal mixture has a better $\mathrm{C} / \mathrm{N}$ ratio, which is 17.7 , while in the first it is 15.5. The biogas production is also higher in the first case, about $17.6 \%$. By comparing the obtained amounts of biogas in both cases, it can be concluded that if WWS is present in the mixture, the biogas production will decrease. From the aspects of OW utilization, in both cases, the problem of OFMSW and HM will be solved, partially in case of CM and PM, and $21.8 \%$ of WWS in the second case. However, other fractions like MS and WS will remain in large amounts. As an overall conclusion, it can be said that the resulting model is not only promising for both cases but also a favourable one, because all fractions are present in the optimal mixture.

\section{REFERENCES}

1. Mata-Alvarez, J., Macé, S., Llabrés, P.: Anaerobic digestion of organic solid wastes. An overview of research achievements and perspectives, Bioresource Technology. Vol. 74, pp.3 - 16, 2000.

2. Agyeman, F. O., Tao, W.: Anaerobic co-digestion of food waste and dairy manure: Effects of food waste particle size and organic loading rate, Journal of Environmental Management, Vol. 133, pp.268 - 274, 2014.

3. Wagner, A. O., Lins, P., Malin, C., Reitschuler, C., Illmer, P.: Impact of protein-, lipid- and cellulosecontaining complex substrates on biogas production and microbial communities in batch experiments, Science of the Total Environment., Vol. 458 - 460, pp. 256 - 266, 2013. 
4. Iacovidou, E., Ohandja, D. G., Voulvoulis, N.: Food waste co-digestion with sewage sludge- Realising its potential in the UK, Journal of Environmental Management, Vol.112, pp. 267 - 274, 2012.

5. Cirne, D. G., Paloumet, X., Björnsson, L. Alves, M.M., Mattiasson, B.: Anaerobic digestion of lipid-rich waste - Effects of lipid concentration, Renewable Energy, Vol. 32 No.6, pp.965 - 975, 2007.

6. Angelidaki, I., Ahring, B.K.: Effects of free long-chain fatty acids on thermophilic anaerobic digestion, Applied Microbiology and Biotechnology, Vol.37, No.6, pp.808 - 812,1992.

7. Alves, M.M., Pereira, M.A., Sousa D. Z., Cavaleiro, A.J., Picavet, M., Smidt, H., Stams, A.J.M.:Waste lipids to energy: how to optimize methane production from long-chain fatty acids (LCFA), Microbial Biotechnology, Vol .2 No.5, pp. $538-550,2009$.

8. Rasit, N., Idris, A., Harun, R., Ghani, W.A.W.A.K.: Effects of lipid inhibition on biogas production of anaerobic digestion from oily effluents and sludges: An overview, Renewable and Sustainable Energy Reviews, Vol. 45, pp.351 - 358, 2015.

9. Long, J. H., Aziz, T. N., de los Reyes III, L. F., Ducoste, J. J.: Anaerobic co-digestion of fat, oil, and grease (FOG): A review of gas production and process limitations, Process Safety and Environmental Protection, Vol. 90, No3, pp. $231-245,2012$.

10. Sun, Y., Wanga, D., Yan, J., Qiao, W., Wang, W., Zhu, T.: Effects of lipid concentration on anaerobic co-digestion of municipal biomass wastes, Waste Management, Vol. 34, pp. 1025 - 1034, 2014

11. Luostarinen, S., Luste, S., Sillanpää, M.: Increased biogas production at wastewater treatment plants through co-digestion of sewage sludge with grease trap sludge from a meat processing plant, Bioresource Technology, Vol.100, No1, pp.79- 85, 2009.

12. Ahring, B. K., Biswas, R., Ahamed, A., Teller, P. J., Uellendahl, H.: Making lignin accessible for anaerobic digestion by wet-explosion pretreatment, Bioresource Technology, Vol.175, pp.182 - 188, 2015.

13. Triolo, J. M., Sommer, S. G., Møller, H. B.,Weisbjerg, M. R., Jiang, X. Y.: A new algorithm to characterize biodegradability of biomass during anaerobic digestion: Influence of lignin concentration on methane production potential, Bioresource Technology, Vol. 102 No.20, pp. 9395 - 9402, 2011.

14. Rajput, A. A., Zeshan, Visvanathan, C.: Eff ect of thermal pretreatment on chemical composition, physical structure and biogas production kinetics of wheat straw, Journal of Environmental Management, Vol. 221, pp. $45-52,2018$.

15. Xie, S., Hai, F. I., Zhan, X., Guo, W., Ngo, H. H., Price, W. E., Nghiem, L. D.: Anaerobic co-digestion: A critical review of mathematical modelling for performance optimization, Bioresource Technology, Vol. 222, pp. $498-512,2016$.

16. Batstone, D. J., Keller, J., Angelidaki, I., Kalyuzhnyi, S.V., Pavlostathis, S.G., Rozzi, A.: The IWA Anaerobic Digestion Model No 1 (ADM1). Water Science and Technology, Vol. 45, No.10, pp. 65-73, 2002.

17. Choi, A. E. S., Park, H. S.: Fuzzy multi-objective optimization case study based on an anaerobic codigestion process of food waste leachate and piggery wastewater, Journal of Environmental Management, Vol.223, pp. $314-323,2018$.

18. Siddiqui, Z., Horan, N.J., Anaman, K.: Optimisation of C:N Ratio for Co-Digested Processed Industrial Food Waste and Sewage Sludge Using the BMP Test, International Journal of Chemical Reactor Engineering, Vol. 9, No. 1, pp.1542-6580, 2011.

19. City of Niš: Official presentation - Available at: http://www.ni.rs/o-nisu/dobrodosli/licna-karta/

20. PUC "Medijana". Official website - Available at: <http://www.jkpmediana.rs/> [accessed 20.12.2016].

21. Public Utility Company "Naissus" Official presentation - Available at: http://www.jkpnaissus.co.rs/

22. Republic Institute for Statistics of Serbia, Available at: http://devinfo.stat.gov.rs/SerbiaProfileLauncher/ files/profiles/sr/1/DI_Profil_Grad\%20Nis_EURSRB002002005001.pdf

23. City of Niš: Official presentation - Available at: http://www.ni.rs/2015/01/01/akti-gradskog-veca-gradanisa-za-2015-godinu/.

24. Stefanović, G., Momčilović, A., Ivanović, M., Milutinović, B., Izbor optimalnog sadržaja sirovine za biološki tretman organskog otpada, Procedings of Udruženje za tehnologiju vode i sanitarno inženjerstvo, Brzeće, Mart 27 - 29, pp $153-161,2018$.

25. Hidaka, T., Wang, F., Tsumori, J.: Comparative evaluation of anaerobic digestion for sewage sludge and various organic wastes with simple modelling, Waste Management, Vol. 43, pp. 144 -151, 2015.

26. Li, M., Xiao, B., Wang, X., Liu, J.: Consequences of sludge composition on combustion performance derived from thermogravimetry analysis, Waste Management, Vol. 35, pp. 141 - 147, 2015.

27. Ruiz-Gómez, N., Quispe, V., Ábrego, J., Atienza-Martínez, M., Benita Murillo, M., Gea, G.: Copyrolysis of sewage sludge and manure, Waste Management, Vol. 59, pp. 211 - 221, 2017.

28. Momčilović, A., Rajković, P., Stojković, N., Milutinović,B., Ivanović, M., Stefanović,G., The Optimization of Organic Waste Fractions Ratio for the Maximum Biogas Yield, Proceedings of SIMTERM, Sokobanja, October 17 -20, pp 796 - 803, 2017. 
29. Sun, C., Cao, W., Banks, C. J., Heaven, S., Liu, R.,: Biogas production from undiluted chicken manure and maize silage: a study of ammonia inhibition in high solids anaerobic digestion, Bioresource Technology, Vol. 218, pp. 1215 - 1223, 2016.

30. Kalamaras, S.D., Kotsopoulos, T.A.: Anaerobic co-digestion of cattle manure and alternative crops for the substitution of maize in South Europe, Bioresource Technology, Vol. 172, pp. 68-75, 2014.

31. Kaparaju, P., Serrano, M., Angelidaki, I.: Optimization of biogas production from wheat straw stillage in UASB reactor, Applied Energy, Vol. 87, No. 12, pp. 3779-3783, 2010.

32. Biernacki, P., Steinigeweg, S., Borchert, A., Uhlenhut, F.: Application of Anaerobic Digestion Model No. 1 for describing anaerobic digestion of grass, maize, green weed silage, and industrial glycerine, Bioresource Technology, Vol. 127, pp. 188 - 194, 2013.

33. Li, R., Duan, N., Zhang, Y., Liu, Z., Li, B., Zhang, D., Lu, H., Dong, T.: Co-digestion of chicken manure and microalgae Chlorella 1067 grown in the recycled digestate: Nutrients reuse and biogas enhancement, Waste Management, Vol 70, pp. 247 - 254, 2017

34. Li, Y., Zhang, R., He, Y., Zhang, C., Liu, X., Chen, C., Liu. G.: Anaerobic co-digestion of chicken manure and corn stover in batch and continuously stirred tank reactor (CSTR), Bioresource Technology, Vol. 156, pp. $342-347,2014$

35. Meyer, A.K.P., Ehimen, E.A., Holm-Nielsen, J.B.: Future European biogas: Animal manure, straw and grass potentials for a sustainable European biogas production, Biomass and Bioenergy, Vol. 111, pp. 154 $-164,2018$.

36. Oslaj, M., Mursec, B., Vindis, P.: Biogas production from maize hybrids, Biomass and Bioenergy, Vol. 34, No. 11, pp. 1538-1545, 2010

\section{OPTIMIZACIJA PROCESA ANEROBNE DIGESTIJE PRIMENOM MULTIKRITERIJUMSKE ANALIZE}

Anaerobna ko-digestija (AcD) različitih frakcija organskog otpada (OV) je dobar način za rešavanje problema upravljanja otpadom i dobijanje energije. Na proces utiču mnogi faktori, kao što su fizičke i hemijske karakteristike otpada. Ovo istraživanje se bavi optimizacijom procesa AcD; razvijen je matematički model, na osnovu karakteristika OV u cilju postizanja maksimalne produkcije biogasa. Različite frakcije OV, koje su dostupne na teritoriji grada, organska frakcija komunalnog otpada (OFKO), kravlji ekskrementi (KE), svinjski ekskrementi (SE), pšenična slama (PS), kukuruzna silaža (KS), živinski ekskrementi (ŽE) i teorijski izračunata količina mulja iz postrojenja za prečišćavanje otpadnih voda (MOV), su posmatrane. Primenom višekriterijumske optimizacije $i$ posmatranjem sadržaja ugljenika, azota, lipida i lignina u OV, razvijen je matematički model. Kriterijumi za model bili su postizanje maksimalnog sadržaja ugljenika i lipida i minimalnog sadržaja azota i lignina. Posmatrane su dve različite mešavine $O V$, prva mešavina uključuje OFKO, KE, SE, $K S, \check{Z} E$, PS. Druga mešavina uključuje frakcije iz prve mešavine i mulj iz postrojenja za pročišćavanje otpadnih voda. Rezultati pokazuju da u sastavu prve optimalne mešavine ulazi 10\% ŽE, 10\%SE $i$ $10 \%$ KS, 24\% OFKO i 34\% KE i 12\% PS. Udeo ugljenika je 44,1\%, azot 2,4\%, lipid 5,8\% i lignin $3,9 \%$, a odnos $C / N$ 17,7. U sastavu druge optimalne mešavine ulazi $10 \%$ ŽE, $10 \%$ SE, $10 \% \mathrm{KS} i$ $10 \%$ MOV, 23\% OFKO, 26\% KE i 11\% PS. Sadržaj ugljenika je 43,2\%, azot 2,7\%, lipid 6,1\% i lignin 4,1\%, odnos $C / N$ 15,6. Sa aspekta produkije biogasa, rezultati su pokazali da prva optimalna mješavina ima 17,6\% veću produkciju od druge optimalne mešavine.

Ključne reči: Anerobna ko - digestija, organski otpad, lipidi, lignin, produkcija biogasa, C/N odnos. 